\title{
HUBUNGAN RELIGIUSITAS, DUKUNGAN SOSIAL DAN TINGKAT STRES TERHADAP PERILAKU COPING ORANG TUA ANAK PENYANDANG DISABILITAS UNIT PELAYANAN DISABILITAS (UPD) KOTA TANGERANG SELATAN
}

\author{
Muhammad Nurman Novian \\ Universitas Indonesia \\ Email: nurmannovian@gmail.com
}

\begin{abstract}
Coping" behavior towards families of children with disabilities is suspected by a variety of parental conditions, such as the spiritual parent in dealing with social problems, parental stress levels and social support will trigger the direction of "coping" behavior of parents with children with disabilities. This study will look at the influence of spiritual variables, social support and stress levels in influencing the "coping" behavior of parents with children with disabilities who receive UPD Tangsel assistance. This research uses a quantitative approach. Based on the techniques in data collection, this research is a survey research. Survey research was carried out through questionnaires and formal interviews to collect information, background, behavior, beliefs and attitudes of people. Data processing was carried out using SPSS 25 software. At the value of the level of religiosity is smaller than $\alpha(0.005)$. So, 0,000 $<0.005$, then Ho is rejected and H1 is accepted. Thus, there is a relationship between the level of religiosity with the level of coping. At the level of social support, the value is smaller than $\alpha(0.005)$. So, 0,000<0.005, then Ho is rejected and H1 is accepted. In the stress level variable, the value is smaller than $\alpha(0.005)$. So, 0,000<0.005, then Ho is rejected and $\mathrm{H} 1$ is accepted. The conclusion is that there is a relationship between the level of religiosity, the level of social support and the level of stress with the level of coping of parents of children with disabilities in the South Tangerang City Disability Service Unit (UPD).
\end{abstract}

Keywords: Coping Stress; Children with Disabilities; South Tangerang UPD.

Abstrak. Perilaku coping terhadap keluarga anak penyandang disabilitas ditengarai oleh berbagai kondisi orang tua, seperti spiritual orangtua dalam menghadapi permasalahan sosialnya, tingkat stres orangtua dan dukungan sosialnya akan memicu arah perilaku coping orangtua dengan anak penyandang disabilitas. Penelitian ini akan melihat pengaruh dari variabel spiritual, dukungan sosial dan tingkat stres dalam mempengaruhi perilaku coping orangtua dengan anak penyandang disabilitas penerima bantuan UPD Tangsel. Penelitian ini menggunakan pendekatan kuantitatif, berdasarkan teknik dalam pengambilan datanya maka penelitian ini merupakan penelitian survei. Penelitian survei dilakukan melalui kuesioner tertulis serta wawancara formal guna mengumpulkan informasi, latar belakang, perilaku, kepercayaan dan sikap orang, pengolahan data dilakukan menggunakan software SPSS 25. Pada nilai tingkat religiusitas lebih kecil dari $\alpha$ (0,005). Sehingga 0,000 < 0,005, maka Ho ditolak dan H1 diterima. Dengan demikian terdapat hubungan tingkat religiusitas dengan tingkat coping. Pada tingkat dukungan sosial nilainya lebih kecil dari $\alpha(0,005)$. Sehingga 0,000<0,005, maka Ho ditolak dan H1 diterima. Pada variabel tingkat stress nilainya lebih kecil dari $\alpha(0,005)$. Sehingga $0,000<$ 0,005, maka Ho ditolak dan H1 diterima. Kesimpulannya yaitu terdapat hubungan antara tingkat religiusitas, tingkat dukungan sosial dan tingkat stress dengan tingkat coping orang tua anak penyandang disabilitas Unit Pelayanan Disabilitas (UPD) Kota Tangerang Selatan.

Kata Kunci: Coping Stress; Anak Penyandang Disabilitas; UPD Tangsel. 


\section{Hubungan Religiusitas, Dukungan Sosial dan Tingkat Stres Terhadap Perilaku Coping Orang Tua Anak Penyandang Disabilitas Unit Pelayanan Disabilitas (UPD) Kota Tangerang Selatan}

Muhammad Nurman Novian

\section{Pendahuluan}

Pada 1993 American Academy of Pediatric menyatakan bahwa kesehatan kronis pada anak merupakan penyakit atau cacat yang diderita dalam waktu yang relatif lama serta diperlukan perhatian khusus dibanding anak normal seusianya, baik dalam perawatan di rumah sakit, maupun di rumah (Rusmil, 2013). Penyakit kronis diantaranya adalah kelainan jantung bawaan, HIV/ AIDS, sickle cell, asma, diabetes, kanker, epilepsi, anemia, obesitas dan penyakit yang berhubungan dengan kemampuan kognitif seperti autis, hiperaktif dan retardasi mental (Maria, Indriati \& Rahmalia, 2013). Setiap orang tua menginginkan anaknya sehat dan tumbuh berkembang secara optimal. Tidak hanya perkembangan secara fisik, tetapi juga perkembangan secara mental. Tetapi, masih terdapat anak-anak yang terlahir dengan keadaan tidak sempurna baik secara mental maupun fisik, seperti anak-anak penyandang disabilitas. Penyandang disabilitas merupakan orang yang mengalami keterbatasan fisik, mental, intelektual dan sensorik sehingga mengalami hambatan berinteraksi dengan lingkungan sekitarnya, sehingga penyandang disabilitas akan kesulitan untuk berpartisipasi di masyarakat (UU Nomor 8 Tahun 2016). Publikasi Badan Pusat Statistik (BPS) menyatakan sekitar 9,9 juta anak Indonesia adalah anak berkebutuhan khusus (ABK) dalam kategori penyandang disabilitas (Winarsih, dkk, 2013). Publikasi Pusdatin Kementerian Kesehatan RI pada tahun 2014 menyatakan jumlah anak yang mengalami disabilitas di Indonesia berdasarkan data Susenas 2012 didapatkan estimasi sebesar 2,45\% dan sekitar 39,97\% nya mengalami disabilitas ganda (Infodatin, 2014).

Permasalahan disabilitas yang terjadi pada anak dapat dilihat dari aspek internal dan eksternal, pada aspek eksternal tidak dapat dipungkiri bahwa masih rendahnya pemahaman keluarga terhadap masalah disabilitas menjadi pengaruh yang paling besar bagi penanganan anak difabel yang kurang tepat. Kurang adanya peran keluarga dan masyarakat dalam penanganannya, kurangnya pemenuhan hak-hak penyandang disabilitas di berbagai aspek kehidupan serta banyak penyandang disabilitas hidup miskin dan tingkat pendidikan yang masih rendah menjadi pemicu semakin terabaikannya penanganan anak-anak disabilitas secara tepat. Perasaan aib memiliki anak penyandang disabilitas membawa dampak terabaikannya pemenuhan penanganan yang tepat bagi anak penyandang disabilitas belum lagi pemenuhan kebutuhan mereka tidak memakan biaya yang sedikit maka hal ini akan menimbulkan permasalahan dan 
memicu stress bagi orangtua si anak.

Menurut Richard (2010) stres merupakan proses menilai suatu peristiwa yang mengancam, atau membahayakan dan individu merespon peristiwa tersebut pada level fisiologis, emosional, kognitif dan perilaku. Dalam perspektif kesejahteraan sosial pada saat individu mengalami disfungsi sosial dikarenakan satu dan lain hal akan mempengaruhi keberfungsian sosialnya dan lingkup sub sistem terdekatnya. Midgley (1997) dalam Adi (2013) mendefinisikan kesejahteraan sosial sebagai suatu keadaan atau kondisi kehidupan manusia yang tercipta ketika berbagai permasalahan sosial dapat dikelola dengan baik.

Coping digunakan mengatasi stres dan hambatan yang dialami. Dalam kamus psikologi (Chaplin, 2002), coping behaviour diartikan suatu perilaku di mana individu melakukan interaksi dengan lingkungan sekitarnya, dengan tujuan menyelesaikan sesuatu. Beberapa penelitian menyangkut faktor yang menjadi penyebab coping stres telah diteliti oleh beberapa ahli. Seperti Bandura (dalam Pargament, 1997) mengatakan optimisme yang muncul dari efikasi diri seseorang memiliki hubungan dengan banyak konsekuensi positif, termasuk kemampuan menghadapi kondisi yang sulit. Melihat situasi dari permasalahan eksternal penyandang disabilitas banyak dari mereka yang berada di bawah garis kemiskinan, sulit bagi orang tua dengan anak penyandang disabilitas untuk memenuhi kebutuhan pengobatan serta penanganan khusus yang memakan biaya yang tidak sedikit. Dalam hal ini perlu adanya dukungan materil, dukungan internal dan eksternal bagi keluarga miskin dalam menghadapi anak penyandang disabilitas. Dukungan yang memenuhi kebutuhan informasi serta emosional yang disalurkan oleh anggota keluarga besar, saudara dan lingkungan masyarakat sekitar adalah hal yang penting dalam menghadapi anak penyandang disabilitas.

Dukungan sosial dewasa ini tidak hanya diperoleh dari internal keluarga itu berada, dukungan sosial juga didapatkan dari eksternal keluarga, yaitu dukungan sosial dari kelompok swabantu yaitu kelompok yang biasanya memberikan bantuan sosial. Kelompok swabantu yang turut andil dalam bidang penanganan anak penyandang disabilitas adalah Unit Pelayanan Disabilitas (UPD) Kota Tangerang Selatan (Tangsel). UPD Tangsel melakukan penyaluran dana yang bertujuan untuk terciptanya penanganan yang komprehensif bagi penyandang disabilitas. Salah satu solusi yang ditawarkan oleh UPD Tangsel untuk menyembatani kesenjangan permasalahan penanganan anak 


\section{Hubungan Religiusitas, Dukungan Sosial dan Tingkat Stres Terhadap Perilaku Coping Orang Tua Anak Penyandang Disabilitas Unit Pelayanan Disabilitas (UPD) Kota Tangerang Selatan}

Muhammad Nurman Novian

penyandang disabilitas adalah dengan menciptakan unit khusus untuk pelayanan bagi disabilitas. Adanya unit khusus atau UPD Tangsel ini diharapkan dapat membantu para orangtua dengan anak penyandang disabilitas untuk menangani anaknya secara tepat dengan pemberian bantuan dana bagi keluarga dengan anak penyandang disabilitas.

Berdasarkan latar belakang yang dikemukakan, perilaku coping terhadap keluarga anak penyandang disabilitas ditenggarai oleh berbagai kondisi orang tua seperti spiritual orangtua dalam menghadapi permasalahan sosialnya, tingkat stres orangtua dan dukungan sosialnya maka akan memicu arah perilaku coping orangtua dengan anak penyandang disabilitas. Maka penelitian ini akan melihat pengaruh dari variabel spiritual, dukungan sosial dan tingkat stres dalam mempengaruhi perilaku coping orangtua dengan anak penyandang disabilitas penerima bantuan UPD Tangsel.

\section{Metode}

Penelitian ini menggunakan pendekatan kuantitatif. Riset kuantitatif berfokus pada pengumpulan serta pengolahan data, menggunakan pendekatan secara deduktif guna melihat hubungan teori serta penelitian. Tujuan penelitian ini masuk kedalam penelitian eksplanasi dengan ciri: menguji prediksi atau prinsip suatu teori, mengelaborasi atau memperkaya penjelasan suatu teori, memperluas teori ke isu baru atau topik baru, mendukung atau menolak penjelasan atau prediksi suatu teori, menghubungkan topik ke prinsip yang lebih umum, memilih penjelasan mana yang paling baik. Berdasarkan teknik pengambilan datanya maka penelitian ini merupakan penelitian survei. Penelitian survei dilakukan dengan menggunakan kuesioner tertulis atau wawancara formal untuk mengumpulkan informasi latar belakang, perilaku, kepercayaan dan sikap dari sejumlah orang.

Untuk pengambilan sampel digunakan metode pengambilan sampel nonprobability sampling. Non probability sampling merupakan teknik pengambilan sampel yang tidak memberikan peluang/kesempatan yang sama bagi unsur atau anggota populasi untuk dipilih menjadi sampel. Teknik non probability sampel yang digunakan adalah kuota sampling. Kuota sampling dilakukan dengan memilih unit sampel berdasarkan karakteristik tertentu sehingga total sampel akan memiliki distribusi yang sama dengan populasi. Pada penelitian ini sampel penelitian ditetapkan sejumlah 60 orangtua dengan anak penyandang disabilitas. 
Penelitian ini menggunakan instrumen kuesioner yang dilakukan dengan cara memberikan seperangkat pertanyaan tertulis kepada responden untuk dijawab. Kuesioner merupakan teknik pengumpulan data yang efisien bila peneliti tahu pasti variabel yang akan diukur dan apa yang diharapkan dari responden (Iskandar, 2000). Kuesioner yang digunakan adalah self-administered with closed -ended question di mana responden mengisi sendiri kuesioner atas sejumlah pertanyaan yang sudah disediakan jawabannya.

Pengolahan data dilakukan dengan menggunakan software SPSS series 25. Tahapannya adalah sebagai berikut: 1) membuat form dan buku kode; 2) mengisi form tersebut dengan informasi yang ada di dalam kuesioner dan menggunakan kode yang sudah dibuat; 3) mengolah data tersebut untuk dapat dianalisis. Setelah data selesai dicoding maka akan dilakukan analisa statistik menggunakan SPSS versi 25. Penelitian ini menggunakan analisis data univariat dan analisis data bivariat. Analisis data univariat merupakan analisis terhadap satu variabel. Dalam menggunakan analisis univariat, peneliti menggunakan statistik deskriptif. Statistik deskriptif bertujuan untuk memberikan gambaran umum tentang objek penelitian. Prosedur statistik deskriptif yang digunakan adalah distribusi frekuensi dari responden.

Selain itu analisa univariat, peneliti juga melakukan analisa data bivariat di mana analisa berusaha melihat hubungan di antara dua variabel. Analisa bivariat dilakukan dengan menggunakan tabulasi silang atau crosstab. Tabulasi silang (Indriatno, dkk, 1998) merupakan metode analisis kategori data yang menggunakan data nominal, ordinal, interval serta kombinasi diantaranya. Hasil tabulasi silang disajikan ke dalam suatu tabel dengan variabel-variabel yang tersusun sebagai kolom dan baris. Analisa tabel silang dapat digunakan untuk mengetahui apakah ada hubungan di antara kedua variabel yang diuji. Pada penelitian ini, kami melakukan analisa tabel silang antara beban kerja dengan tingkat stres kerja, dukungan sosial dengan tingkat stres kerja dan kepuasan leisure dengan tingkat stres kerja. Validitas menurut Azwar (2013) merupakan sejauh mana keakuratan suatu tes jika suatu tes telah dinyatakan memiliki validitas yang tinggi, maka tes tersebut memiliki keakuratan yang tinggi juga.

\section{Hasil dan Diskusi}

Tingkat Religiusitas dari responden terbagi atas dua tingkatan, yaitu 1) Rendah; 2) Tinggi. Pada dasarnya tingkat Religiusitas sangat signifikan 


\section{Hubungan Religiusitas, Dukungan Sosial dan Tingkat Stres Terhadap Perilaku Coping Orang Tua Anak Penyandang Disabilitas Unit Pelayanan Disabilitas (UPD) Kota Tangerang Selatan}

Muhammad Nurman Novian

perbedaannya antara orangtua anak penyandang disabilitas yang memiliki tingkat religiusitas tinggi dengan orangtua anak penyandang disabilitas yang memiliki tingkat religiusitas rendah. Responden yang yang memilih tingkat religiusitas yang tinggi maupun rendah yaitu sama-sama berjumlah 30 orang. Tingkat Dukungan Sosial dari responden terbagi atas dua tingkatan, yaitu 1) Rendah; 2) Tinggi. Pada dasarnya tingkat Dukungan Sosial sangat signifikan perbedaannya antara orang tua anak penyandang disabilitas yang memiliki tingkat Dukungan Sosial tinggi dengan orang tua anak penyandang disabilitas yang memiliki tingkat Dukungan Sosial rendah. Responden yang memiliki tingkat Dukungan Sosial yang tinggi maupun rendah yaitu sama-sama berjumlah 27 orang dengan prosentase $45 \%$. Tingkat Stress dari responden terbagi atas dua tingkatan, yaitu 1) Rendah; 2) Tinggi. Pada dasarnya tingkat stress sangat signifikan perbedaannya antara orangtua anak penyandang disabilitas yang memiliki tingkat stress tinggi dengan orangtua anak penyandang disabilitas yang memiliki tingkat stress rendah. Responden yang yang memilih tingkat rendah berjumlah 36 dengan persentase $60 \%$ sedangkan yang tinggi berjumlah 24 dengan persentase $40 \%$.

Untuk melihat ada tidaknya hubungan antara tingkat religiusitas dengan tingkat coping, dilakukan dengan membuat tabulasi silang antara tingkat religiusitas dengan tingkat coping. Dari hasil penelitian terlihat bahwa semakin tinggi tingkat religiusitas, semakin tinggi pula tingkat coping yang dialami oleh responden. Begitu juga ketika tingkat religiusitas rendah, tingkat coping yang dialami oleh responden juga rendah. Hal ini dapat diartikan bahwa terdapat hubungan yang sangat tinggi antara tingkat religiusitas dengan tingkat coping. Dari hasil penelitian dapat disimpulkan adanya hubungan yang sangat signifikan antara tingkat religiusitas dengan tingkat coping $(0,000)$. Pada nilai tingkat religiusitas tersebut lebih kecil dari $\alpha(0,005)$. Sehingga $0,000<0,005$, maka Ho ditolak dan H1 diterima. Dengan demikian terdapat hubungan antara tingkat religiusitas dengan tingkat coping. Dari hasil uji bisa dilihat bahwa tingkat coping sebagai dependen menunjukkan nilai 0,800. Dengan menggunakan skala kekuatan hubungan, maka nilai 0,833 bisa dikatakan memiliki hubungan yang sangat kuat dengan variabel religiusitas sebagai variabel independen.

Ada tidaknya hubungan antara tingkat Dukungan Sosial dengan tingkat coping, dilakukan dengan membuat tabulasi silang antara tingkat Dukungan Sosial dengan tingkat coping. Dari hasil penelitian terlihat bahwa semakin 
tinggi tingkat Dukungan Sosial, semakin tinggi pula tingkat coping yang dialami oleh responden. Begitu juga ketika tingkat Dukungan Sosial rendah, tingkat coping yang dialami oleh responden juga rendah. Hal ini dapat diartikan bahwa terdapat hubungan yang sangat tinggi antara tingkat Dukungan Sosial dengan tingkat coping. Dari hasil penelitian dapat disimpulkan adanya hubungan yang sangat signifikan antara tingkat Dukungan Sosial dengan tingkat coping $(0,000)$. Sehingga $0,000<0,005$, maka Ho ditolak dan H1 diterima. Kesimpulannya yaitu terdapat hubungan antara tingkat Dukungan Sosial dengan tingkat coping. Dari hasil uji bisa dilihat bahwa tingkat coping sebagai dependen menunjukkan nilai 0,492 . Dengan menggunakan skala kekuatan hubungan, maka nilai 0,492 bisa dikatakan memiliki hubungan yang sangat kuat dengan variabel Dukungan Sosial sebagai variabel independen.

Untuk melihat ada tidaknya hubungan antara tingkat stress dengan tingkat coping, dilakukan dengan membuat tabulasi silang antara tingkat stres dengan tingkat coping. Dari hasil penelitian terlihat bahwa semakin rendah tingkat stres, semakin tinggi pula tingkat coping yang dialami oleh responden. Begitu juga ketika tingkat stress tinggi, tingkat coping yang dialami oleh responden juga rendah. Hal ini dapat diartikan bahwa terdapat hubungan yang sangat tinggi antara tingkat stress dengan tingkat coping. Dari hasil ini dapat disimpulkan adanya hubungan yang sangat signifikan antara tingkat stress dengan tingkat coping $(0,000)$. Nilai tingkat stress lebih kecil dari $\alpha(0,005)$. Sehingga $0,000<0,005$, maka Ho ditolak dan H1 diterima. Kesimpulannya yaitu terdapat hubungan antara tingkat stress dengan tingkat coping. Dari hasil uji bisa dilihat bahwa tingkat coping sebagai dependen menunjukkan nilai 0,583 . Dengan menggunakan skala kekuatan hubungan, maka nilai 0,583 bisa dikatakan memiliki hubungan yang sangat kuat dengan variabel tingkat stress sebagai variabel independen.

\section{Kesimpulan}

Dari hasil penelitian dapat disimpulkan bahwa terdapat hubungan antara tingkat religiusitas, dukungan sosial dan tingkat stress dengan tingkat coping pada perilaku coping orang tua anak penyandang disabilitas Unit Pelayanan Disabilitas (UPD) Kota Tangerang Selatan. 
- Muhammad Nurman Novian

\section{Daftar Pustaka}

Prihatin dkk. (2012). Konsep Diri, Kecerdasan Emosional, Tingkat Stres dan Strategi Koping Remaja pada Berbagai Model Pembelajaran. Departemen Ilmu Keluarga dan Konsumen, Fakultas Ekologi Manusia, IPB, Bogor.

Golisz, A. (2005). 60 Second Manajemen Stres. Jakarta: PT. Buana Ilmu Populer. Walia. (2005). Hidup Tanpa Stres. Jakarta: Bina Ilmu Populer.

Hawari. (1997). Al-Qur'an dan Ilmu Kedokteran Jiwa dan Kesehatan Jiwa. Jakarta: Dana Bakti Prima Yasa.

Acok, D., \& Suroso, F. N. (2011). Psikologi Islami. Solusi Islam atas ProblemProblem Psikologi. Jogjakarta: Pustaka Pelajar.

Glock, C. Y., \& Stark, R. (1965). Religion and Society in Tension. Chicago: Rand McNally.

Glock, C. Y., \& Stark, R. (1966). Christian Beliefs and Anti-semitism. New York: Harper \& Row.

Darmawanti, I. (2012). Hubungan antara Tingkat Religiusitas dengan Kemampuan dalam Mengatasi Stres (Coping Stres), Teori \& Terapan, Vol. 2, No. 2. Program Studi Psikologi Universitas Negeri Surabaya.

Sapuan, I. (2014). Hubungan Tingkat Religiusitas dengan Koping Ibu yang Memiliki Anak Retardasi Mental di SLB Negeri 2 Yogyakarta. Program Studi Ilmu Keperawatan Sekolah Tinggi Ilmu Kesehatan 'Aisyiyah Yogyakarta.

Saputra, S.D. (2016). Pengaruh Religiusitas terhadap Manajemen Stres pada Siswa Kelas XII SMA Negeri 1 Kasihan. Program Studi Bimbingan dan Konseling, Jurusan Psikologi Pendidikan dan Bimbingan Fakultas Ilmu Pendidikan Universitas Negeri Yogyakarta.

Dewi, T.K. (2012). The Ideological Dimension of Religiosity: Is It Primarily Expresion of Religiosity? Fakultas Psikologi Universitas Airlangga Surabaya. 